\title{
Milk Lipid and Protein Profiles of Abkhazian and Kackar Goats
}

\author{
H. Iskender, ${ }^{\mathrm{a}, *}$, O. Kaynar ${ }^{\mathrm{b}}$, A. Hayirlic ${ }^{\mathrm{c}}$ \& Y. Camadan $^{\mathrm{d}}$ \\ aDepartment of Nutrition and Dietetics, Faculty of Health Sciences, Artvin Coruh University, \\ Artvin 08000, Turkey \\ bepartment of Biochemistry, Faculty of Veterinary Medicine, Ataturk University, \\ Erzurum 25240, Turkey \\ cDepartment of Animal Nutrition and Nutritional Disorders, Faculty of Veterinary Medicine, Ataturk University, \\ Erzurum 25240, Turkey \\ dDepartment of Pharmacy Services, Vocational School of Health Sciences, Artvin Coruh University, \\ Artvin 08000, Turkey \\ *Email of corresponding author: haticeiskender2011@hotmail.com \\ (Received 22-11-2017; Reviewed 20-12-2017; Accepted 18-01-2018)
}

\begin{abstract}
Fat and protein profiles of milk of Abkhazian and Kackar goats, Caucasian breeds, were compared in this study. The milk samples $(n=60)$ from 60 Abkhazian and Kackar goats were subjected to assessments of lipid profile using the high performance thin layer chromatography and protein profile using the sodium dodecyl sulphate polyacrylamide gel electrophoresis. The milk lipid and protein contents as well as their fractions were compared using student $t$-test. Total lipid content was $4.23 \pm 0.022 \mathrm{~g} / \mathrm{dl}$ and $3.44 \pm 0.026 \mathrm{~g} / \mathrm{dl}$ for Abkhazian and Kackar goat milk $(\mathrm{P}<0.0001)$. Milk triacylglycerol, free fatty acid and diacylglycerol fractions were different $(\mathrm{P}<0.05)$, but the cholesterol fraction was similar. Total protein content was $3.94 \mathrm{~g} / \mathrm{dl}$ and $3.75 \mathrm{~g} / \mathrm{dl}$ for Abkhazian and Kackar goat milk $(\mathrm{P}<0.007)$. The milk fat globule membrane protein mucine1 and xhantine oxidase, $\alpha$-lactalbumin, $\alpha$-casein, and $\kappa$-casein fractions were different $(\mathrm{P}<0.05)$. In conclusion, milk lipid and protein profile differs between Abkhazian and Kackar goats despite living in the same ecosystem. Differences in milk lipid and protein profile could be pertinent to human nutrition and health.
\end{abstract}

Keywords: goat milk, lipid profile, protein profile

\section{INTRODUCTION}

Milk is a complex biological fluid, abundant in nutrients (Drewnowski \& Fulgoni, 2008). The consumption of goat milk increases as it has become a subject of a number of versatile research areas. Goat milk differs from cow or human milk, in terms of higher digestibility, distinct alkalinity, higher buffering capacity, and certain therapeutic values in human medicine and nutrition (Raynal-Ljutovaca et al., 2008). It exerts beneficial effects for paediatric and geriatric health and nutrition through aiding physiological functions and can be consumed without negative effects by people suffering from allergy to cow milk (Yangilar, 2013).

Compositions of human, sheep, goat, and cow milks are different, especially the structure, composition, and dimension of casein micelles, individual protein fractions and non-protein nitrogen amount as well as mineral concentration (Kucukcetin et al., 2011; Domagala, 2009). Moreover, in comparison with cow milk protein, goat milk proteins are more digestible (Ceballos et al., 2009) and the protein fraction has higher levels of six of the ten essential amino acids present (Costa et al., 2014). Another important property is that goat milk fat contains high amount of short and medium chain fatty acids and their fat globules are small (Silanikove et al., 2010). Goat milk fat is known to be rich in caproic $\left(\mathrm{C}_{6: 0}\right)$, caprylic $\left(\mathrm{C}_{8: 0}\right)$, and capric $\left(\mathrm{C}_{10: 0}\right)$ acids as compared to sheep and cow milk (Markiewicz-Kęszycka et al., 2013).

Biochemical composition, technological properties, and bacteriological quality of goat milk vary depending on genetic factors, environmental conditions, and raising conditions (Yangilar, 2013). Different goat breeds are raised in many parts of the world for the purposes of food supply and economical gains. Traditionally, goat milk has been considered as a fundamental food in the diets of many cultures. Abkhazian \& Kackar goats are local breeds and weigh about $40-135 \mathrm{~kg}$ and have wooly coat and short tail. They adapt to mountainous regions and rainy/foggy climate. Kacgar goat is raised in Northeastern Turkey by the Black Sea region. Abkhazian goat is originally Abkhazian region animal, but is also raised in the Black Sea Region of Turkey. This experiment was conducted to compare the fat and protein compositions of the milk of Abkhazian and Kackar goats traditionally raised in the Black Sea Region of Turkey. 


\section{MATERIALS AND METHODS}

\section{Sampling}

The milk samples were collected from 30 Abkhazian and 30 Kackar goats that were in the age of 2-3 years and were reared in two different uplands in Artvin Province in the Black Sea Region of Turkey. Samples were shipped to the laboratory in a few hours under refrigerator conditions and stored at $-80^{\circ} \mathrm{C}$ until analyses.

\section{Determination of Triglyceride Concentration}

To $100 \mu \mathrm{L}$ milk sample, $1 \mathrm{~mL}$ triglyceride reagent [(4-Chlorophenol $3.5 \mathrm{mM}$, ATP >0.5 mM, magnesium salt $10 \mathrm{mM}$, 4-Aminophenazone $0.3 \mathrm{mM}$, microbial glycerol kinase $>250 \mathrm{U} / \mathrm{L}$, microbial glycerol phosphate oxidase $>4500 \mathrm{U} / \mathrm{L}$, horseradish peroxidase $>2000 \mathrm{U} / \mathrm{L}$, microbial lipase $>200.000 \mathrm{U} / \mathrm{L}$, buffer $(\mathrm{pH} 7.3)$, sodium azide $(0.01 \%)$ ] was added. After $30 \mathrm{~min}$ of incubation, absorbances of samples were measured at $505 \mathrm{~nm}$ (Fossati \& Prencipe, 1982). Results were calculated by using a standard triglyceride (TG) solution $(50 \mathrm{mg} / \mathrm{dl})$ and expressed as g TG/dl.

\section{Lipid Profile Analysis}

Milk lipid profile was assessed using the high performance thin layer chromatography (HPTLC). Five hundred $\mu \mathrm{l}$ of $\mathrm{n}$-hexane:iso-propanol 3:2 (v/v) mixture were added into $1 \mathrm{~mL}$ of milk. After vortexing vigorously, the tubes were centrifuged at $5.000 \mathrm{~g}$ for $5 \mathrm{~min}$ at $+4^{\circ} \mathrm{C}$, and the upper phase were used for HPTLC analysis (Hara \& Radin, 1978). A standard lipid mixture comprising L- $\alpha$-phosphatidylcholine, cholesterol, palmitic acid, triolein, glycerol di-oleate, and cholesterol 3-oleate was used to identify milk lipid classes. One $\mu \mathrm{L}$ portion of the control standard and extracted lipid was spotted with a micropipette $2 \mathrm{~cm}$ away from the bottom of the HPTLC plates.

The lipid spots were developed using developing solvent. Then, the entire plate was sprayed with a $10 \%$ $\mathrm{CuSO}_{4}(\mathrm{w} / \mathrm{v})$ in $8 \% \mathrm{H}_{3} \mathrm{PO}_{4}(\mathrm{v} / \mathrm{v})$ and lipid classes were visualized by charring at $180^{\circ} \mathrm{C}$ for about $10 \mathrm{~min}$. Milk lipids were separated into the following classes: cholesteryl ester (CE), triacylglycerol (TAG), free fatty acids (FFA), cholesterol (CHOL), diacylglycerol (DAG), and phospholipids (PL) (Table 1, Figure 1).

HPTL chromatograms were scanned with photoscanner and analyzed with TL 120 software. Results were obtained as percentage of individual lipid class in total lipid of milk samples (Kaynar et al., 2013).

\section{Determination of Total Protein Concentration}

In order to determine total protein concentration, 1 $\mathrm{mL}$ of milk sample was mixed with $0.5 \mathrm{~mL}$ sodiumdeoxycholate $(10 \%)$ and $0.5 \mathrm{~mL}$ trichloroacetic acid $(10 \%)$. The mixture was then incubated in $37^{\circ} \mathrm{C}$ for $30 \mathrm{~min}$ and centrifuged at 5,000xg at $+4^{\circ} \mathrm{C}$ for $5 \mathrm{~min}$. The precipitate was dissolved in $5.0 \mathrm{~mL} 0.1 \mathrm{~N} \mathrm{NaOH}$. Further, $5.0 \mathrm{~mL}$ alkaline copper reagent was added into the same tube.
After $10 \mathrm{~min}, 0.5 \mathrm{~mL}$ folin reagent was added and incubated at room temperature for $30 \mathrm{~min}$. Finally absorbance values of the samples and protein standards were recorded at $660 \mathrm{~nm}$ at spectrophotometer ( $\mu$-Quant, BioTek) against the blank solution (Lowry et al., 1951). Results were calculated by using a standard albumin solution $(5 \mathrm{~g} / \mathrm{dL})$ and expressed as $\mathrm{g} \mathrm{TP} / \mathrm{dl}$.

\section{Protein Profile Analysis}

Individual milk proteins were attained using the sodium dodecyl sulphate polyacrylamide gel electrophoresis (SDS-PAGE), consisting of $4 \%$ stacking and $10 \%$ resolving gels (Laemmli, 1970). Briefly, $10 \mu \mathrm{L}$ of milk sample and $90 \mu \mathrm{L}$ electrophoresis denaturing sample buffer $(0.8 \mathrm{~mL}$ glycerol, $1.6 \mathrm{~mL} 10 \%$ SDS, $0.2 \mathrm{~mL}$ $0.05 \%$ bromophenol blue in ethanol, $1 \mathrm{~mL} 0.5 \mathrm{M}$ tris- $\mathrm{HCl}$ $\mathrm{pH} 6.8,0.4 \mathrm{~mL} \beta$-mercaptoethanol, and $4 \mathrm{~mL}$ distilled water) were mixed and $15 \mu \mathrm{L}$ of mixtures were loaded into each well. The electrophoresis was carried out in tris-glycine running buffer $\mathrm{pH} 8.3$ (Trizma base $1.515 \mathrm{~g}$, glycine $7.2 \mathrm{~g}$, SDS $0.25 \mathrm{~g}, 500 \mathrm{~mL}$ ) at $20 \mathrm{~mA} / \mathrm{gel}$ constant current for $90 \mathrm{~min}$ and proteins were visualized by Oriole fluorescent staining.

SDS-PAGE electrophoretograms (Figure 2) were visualized with GelDoc XR (BioRad) and analyzed with Image Lab software (Figure 3, Table 2). Milk proteins [MFGM (milk fat globule membrane protein/mucine1 (MUC1), xhantine oxidase (XO), cluster of differentiation (CD), butyrophilin (BTN) periodic acid schift (PAS), and WAP (whey acidic protein)] were reported as the percentages within the total protein.

\section{Statistical Analysis}

The difference between lipid and protein parameters of goat milk were determined using student $t$-test (SAS, 2002). Due to missing data and possible unequal variance within groups for some parameters, the Satterthwaite approximation was employed to attain true probability of significance. The data were presented as mean $\pm S E$ as well as group mean difference $\pm S E$. Group differences were considered at $\mathrm{P}<0.05$.

\section{RESULTS}

\section{Lipid Profile}

The lipid profiles of Abkhazian and Kackar goats are shown in Table 1. Milk fat content for Abkhazian goat was higher than that for Kackar goat (4.23 vs. 3.44 $\mathrm{g} / \mathrm{dl} ; \mathrm{P}<0.0001)$. The TAG percentage was higher in Abkhazian goat (68.65 vs. $67.37 \%$; $P<0.0001)$, while the FFA (2.87 vs. $2.08 \%$; $\mathrm{P}<0.0002)$ and DAG (2.87 vs. $2.37 \%$; $\mathrm{P}<0.0001)$ percentages were higher in Kackar goat. They had similar percentages of CHOL and CE.

\section{Protein Profile}

Total protein amounts were 3.94 and $3.75 \mathrm{~g} / \mathrm{dl}$ for Abkhazian and Kackar goat milk ( $\mathrm{P}<0.007$; Table 2). As revealed by the SDS-PAGE method, the molecule weights of MFGM proteins, caseins, and whey proteins 
were determined to be in the range of $10 \mathrm{kDa}$ to 162 $\mathrm{kDa}$ (Figure 1). The molecular weights of $\mathrm{XO}, \mathrm{CD} 36$, BTN, and PAS 6/7, which are the other MFGM proteins in the milk, were calculated to be $80.7 \mathrm{kDa}, 66.0 \mathrm{kDa}$,
$59.9 \mathrm{kDa}$, and $54.49 \mathrm{kDa}$, respectively (Figure 1). The percentages of MUC1, XO, CD36, BTN, and PAS 6/7 in total protein were $1.43 \%, 1.45 \%, 2.53 \%, 1.25 \%$, and $2.70 \%$ for Abkhazian goat and $0.78 \%, 2.18 \%, 2.49 \%$,

Table 1. Comparison of milk lipid profile

\begin{tabular}{lcccccc}
\hline \multirow{2}{*}{ Variables } & \multicolumn{2}{c}{ Caucasian goat breed } & \multirow{2}{*}{ Difference } & \multirow{2}{*}{$t$} & \multirow{2}{*}{$P>|t|$} \\
\cline { 2 - 3 } \cline { 2 - 3 } Total lipid, g/dl & $4.23 \pm 0.02(4.19-4.28)^{\mathrm{a}}$ & $3.44 \pm 0.03(3.39-3.50)^{\mathrm{b}}$ & & $0.79 \pm 0.03$ & 22.93 & 0.000 \\
Lipid classes, $\%^{1}$ & & & & & \\
CE & $19.59 \pm 0.23(19.11-20.07)$ & $19.37 \pm 0.17(19.01-19.72)$ & & $0.23 \pm 0.29$ & 0.79 & 0.43 \\
TAG & $68.65 \pm 0.24(68.16-69.14)^{\mathrm{a}}$ & $67.37 \pm 0.18(67.01-67.73)^{\mathrm{b}}$ & & $1.28 \pm 3.30$ & 4.31 & 0.000 \\
FFA & $2.08 \pm 0.11(1.86-2.30)^{\mathrm{b}}$ & $2.87 \pm 0.16(2.53-3.20) \mathrm{a}$ & & $-0.79 \pm 0.20$ & -4.04 & 0.000 \\
CHOL & $3.49 \pm 0.12(3.25-3.73)$ & $3.49 \pm 0.14(3.22-3.77)$ & & $-0.01 \pm 0.18$ & -0.04 & 0.97 \\
DAG & $2.37 \pm 0.07(2.23-2.51)^{\mathrm{b}}$ & $2.87 \pm 0.08(2.70-3.04)^{\mathrm{a}}$ & & $-0.50 \pm 0.11$ & -4.6 & 0.000 \\
PL & $3.82 \pm 0.08(3.66-3.99)$ & $4.00 \pm 0.09(3.82-4.18)$ & & $-0.18 \pm 0.12$ & -1.48 & 0.14 \\
\hline
\end{tabular}

Note: *Data are mean \pm SE (lower and upper CI, 95\%). Fraction was calculated based on relative volume in HPTLC. Means in the same row with different superscripts differ significantly $(\mathrm{P}<0.05) .{ }^{1} \mathrm{HC}+\mathrm{CE}=$ hydrocarbon + cholesterol ester; $\mathrm{TAG}=$ triacylglycerol; $\mathrm{FFA}=\mathrm{free}$ fatty acids; $\mathrm{CHOL}=$ cholesterol; DAG= diacylglycerol; $\mathrm{PL}=$ phospholipids.
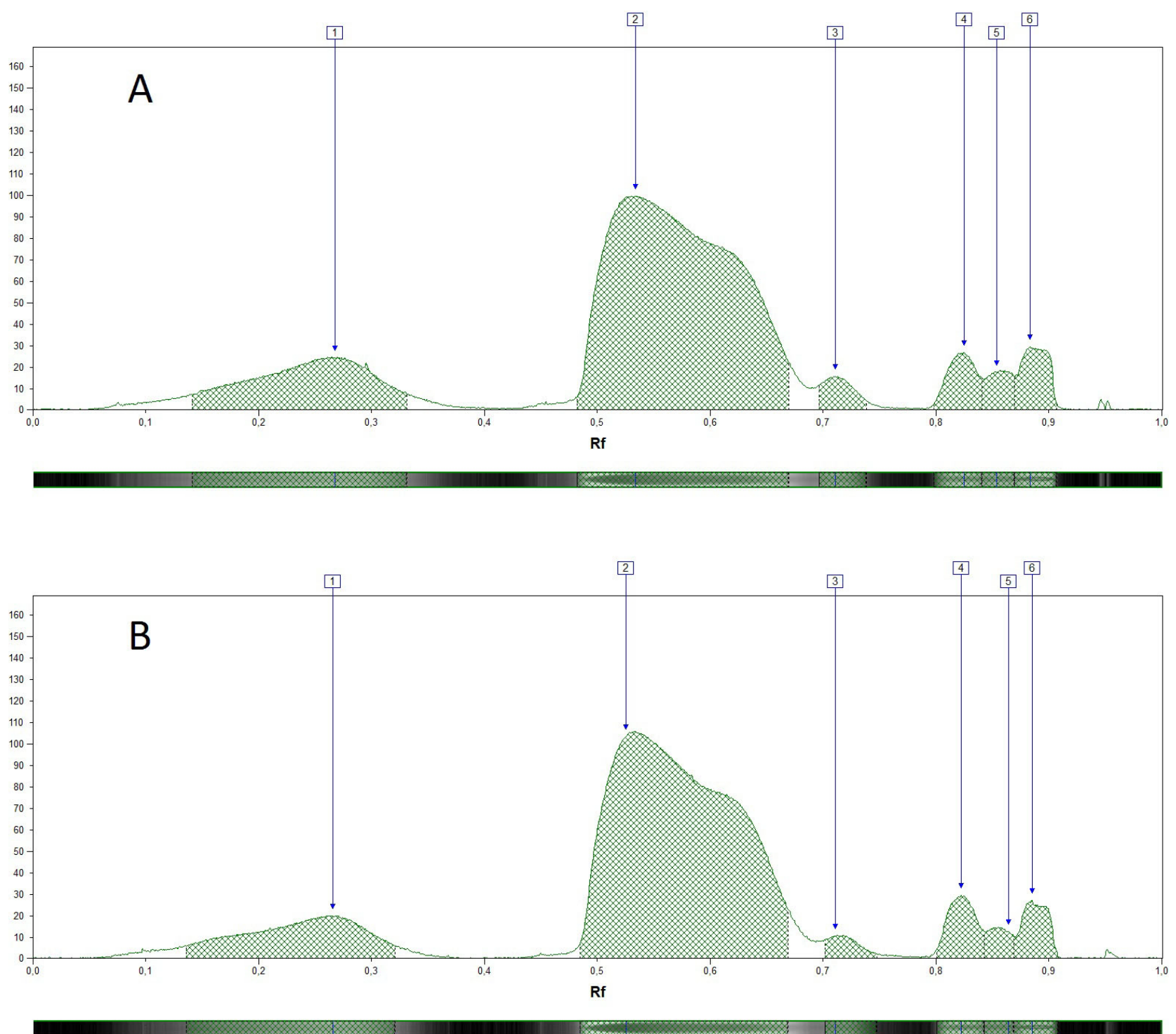

Figure 1. Abkhazian (upper panel) and Kackar (lower panel) goat milk lipid densitograms 
$1.36 \%$, and $2.50 \%$ for Kackar goat, respectively (Table 2 ). The percentages of MUC1 and XO proteins among MFGM proteins were significantly different between goat breeds. It was determined that the percentage of MUC1 protein was higher in Abkhazian goats (1.43\% vs. $0.78 \%$; $\mathrm{P}<0.0001$ ), while the percentage of $\mathrm{XO}$ protein was higher in Kackar goats $(2.18 \%$ vs. $1.45 \%$; $\mathrm{P}<0.0002)$.

The percentages of $\alpha$-casein, $\beta$-casein, and א-casein were $7.13 \%, 40.01 \%$, and $7.6 \%$, respectively, for Abkhazian goat and $10.24 \%, 39.46 \%$, and $9.20 \%$, respectively, for Kackar goat. The percentages of $\alpha$-casein and $\kappa$-casein for Kackar goat were higher than those for Abkhazian goat $(\mathrm{P}<0.0001)$.

The percentages of $\beta$-lactoglobin in Abkhazian and Kackar goats were $6.56 \%$ and $6.78 \%$, respectively, while percentages of $\alpha$-lactalbumin were $7.94 \%$ and $6.68 \%$,

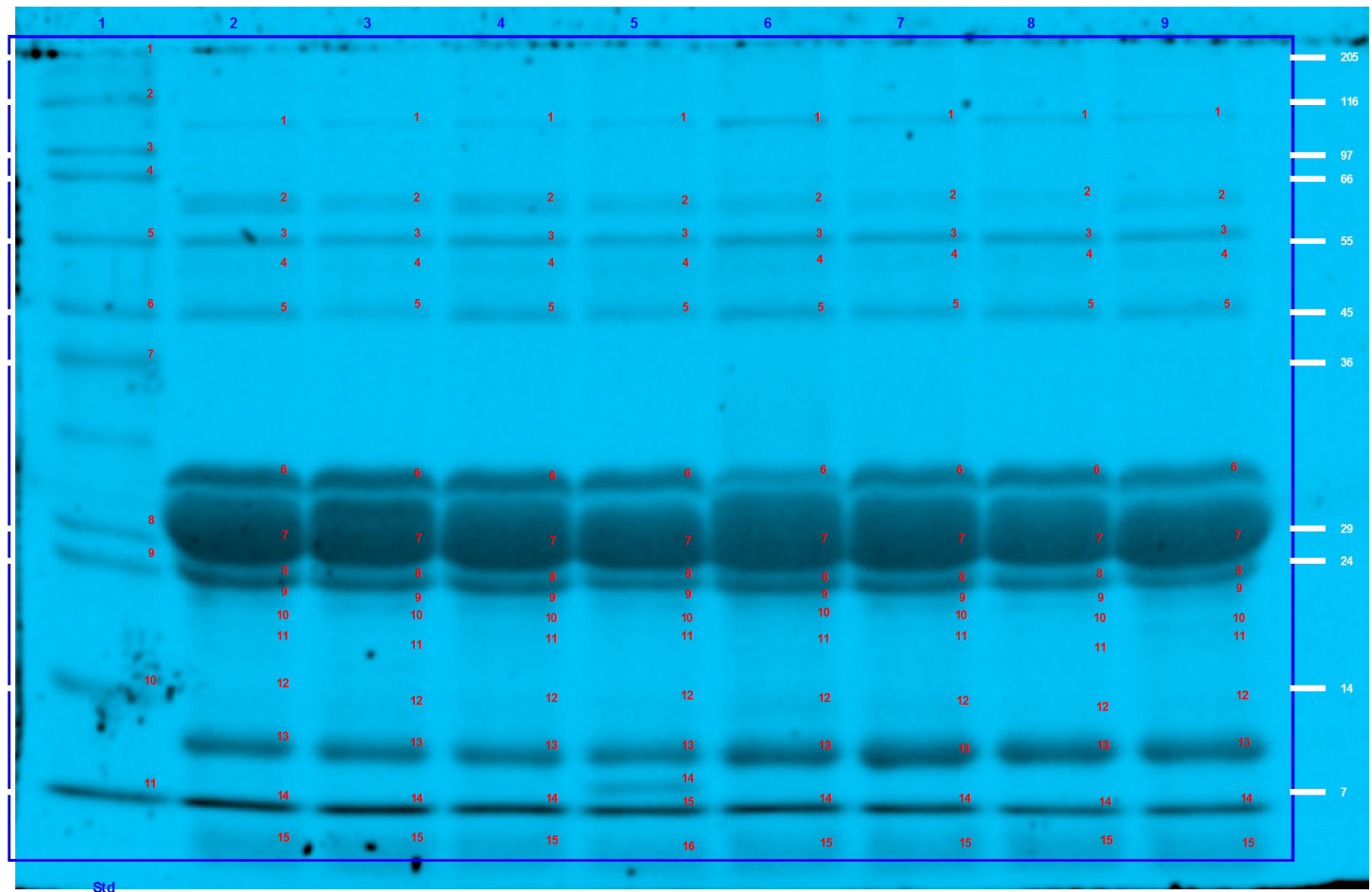

Figure 2. SDS-PAG electrophoretogram of Abkhazian and Kackar goat milk proteins (x-axis: Lanes, y-axis: kD).

Table 2. Comparison of milk protein profile

\begin{tabular}{|c|c|c|c|c|c|c|}
\hline \multirow{2}{*}{ Variables } & & \multicolumn{2}{|c|}{ Caucasian goat breed } & \multirow{2}{*}{ Difference } & \multirow{2}{*}{$t$} & \multirow{2}{*}{$P>|t|$} \\
\hline & & Abkhazian & Kackar & & & \\
\hline Total protein, g/dl & & $3.94 \pm 0.06(3.83-4.06)^{a}$ & $3.75 \pm 0.04(3.67-3.83)^{b}$ & $0.58 \pm 0.21$ & 2.8 & 0.007 \\
\hline Protein, $\%^{1}$ & MW, Da & & & & & \\
\hline MFGM proteins MUC1 & 161921 & $1.43 \pm 0.04(1.34-1.52)^{a}$ & $0.78 \pm 0.03(0.72-0.85)^{b}$ & $0.64 \pm 0.05$ & 12.47 & 0.000 \\
\hline MFGM proteins XO & 80709 & $1.45 \pm 0.14(1.16-1.75)^{b}$ & $2.18 \pm 0.10(1.98-2.39)^{a}$ & $-0.73 \pm 0.17$ & -4.31 & 0.000 \\
\hline MFGM proteins CD36 & 66000 & $2.53 \pm 0.06(2.40-2.66)$ & $2.49 \pm 0.07(2.34-2.63)$ & $0.04 \pm 0.09$ & 0.43 & 0.67 \\
\hline MFGM proteins BTN & 59988 & $1.25 \pm 0.04(1.16-1.34)$ & $1.36 \pm 0.05(1.25-1.48)$ & $-0.11 \pm 0.07$ & -1.66 & 0.11 \\
\hline MFGM proteins PAS6/7 & 54498 & $2.70 \pm 0.10(2.48-2.92)$ & $2.50 \pm 0.08(2.33-2.67)$ & $0.20 \pm 0.13$ & 1.53 & 0.14 \\
\hline$\alpha$-casein & 33754 & $7.13 \pm 0.47(6.44-8.14)^{b}$ & $10.24 \pm 0.26(9.68-10.80)^{a}$ & $-3.11 \pm 0.54$ & -5.74 & 0.000 \\
\hline$\beta$-casein & 26589 & $40.01 \pm 0.63(38.68-41.34)$ & $39.46 \pm 0.84(37.68-41.25)$ & $0.55 \pm 1.05$ & 0.53 & 0.6 \\
\hline$\kappa$-casein & 21670 & $7.68 \pm 0.15(7.35-8.01)^{\mathrm{b}}$ & $9.20 \pm 0.23(8.71-9.69)^{a}$ & $-1.52 \pm 0.28$ & -5.5 & 0.000 \\
\hline WAP & 20505 & $2.22 \pm 0.08(2.04-2.40)$ & $2.31 \pm 0.14(2.01-2.61)$ & $-0.09 \pm 0.16$ & -0.56 & 0.58 \\
\hline WAP & 20007 & $1.59 \pm 0.07(1.44-1.72)$ & $1.52 \pm 0.13(1.25-1.80)$ & $0.06 \pm 0.14$ & 0.42 & 0.68 \\
\hline WAP & 19968 & $1.09 \pm 0.06(0.97-1.20)$ & $1.04 \pm 0.08(0.88-1.20)$ & $0.05 \pm 0.09$ & 0.5 & 0.62 \\
\hline WAP & 19665 & $2.36 \pm 0.12(2.10-2.61)^{\mathrm{a}}$ & $1.86 \pm 0.12(1.60-2.13)^{b}$ & $0.49 \pm 0.17$ & 2.87 & 0.008 \\
\hline WAP & 17723 & $14.08 \pm 0.42(13.19-14.98)^{\mathrm{a}}$ & $11.60 \pm 0.26(11.05-12.14)^{b}$ & $2.49 \pm 0.49$ & 5.06 & 0.000 \\
\hline$\beta$-lactoglobulin & 13547 & $6.56 \pm 0.24(6.04-7.08)$ & $6.78 \pm 0.26(6.22-7.35)$ & $-0.22 \pm 0.36$ & -0.6 & 0.55 \\
\hline$\alpha$-lactalbumin & 10528 & $7.94 \pm 0.37(7.15-8.74)^{a}$ & $6.68 \pm 0.18(6.30-7.05)^{b}$ & $1.27 \pm 0.41$ & 3.07 & 0.006 \\
\hline
\end{tabular}

Note: *Data are mean \pm SE (lower and upper CI, 95\%). Fraction was calculated based on relative volume in SDS-PAGE. Means in the same row with different superscripts differ significantly $(\mathrm{P}<0.05)$. ${ }^{1} \mathrm{MFGM}=$ milk fat globule membrane protein/mucine1 (MUC1), xhantine oxidase $(\mathrm{XO})$, cluster of differentiation (CD), butyrophilin (BTN) periodic acid schift; WAP $=$ whey acidic protein. 

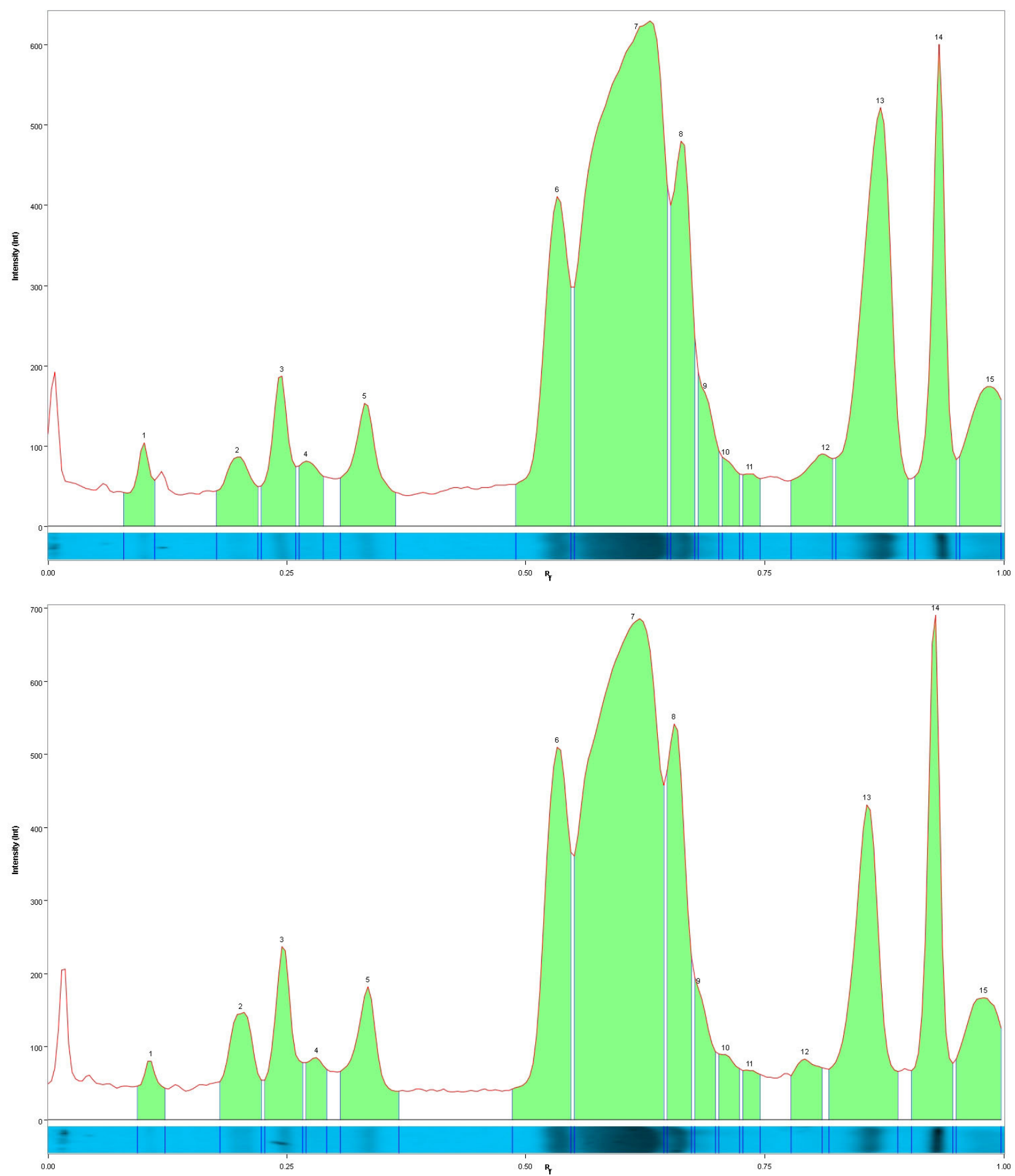

Figure 3. Abkhazian (upper panel) and Kackar (lower panel) goat milk protein densitograms

respectively. $\alpha$-Lactalbumin fraction between breeds was different $(\mathrm{P}<0.006)$, but $\beta$-lactoglobin fraction was similar.

\section{DISCUSSION}

It is known that significant variations occur in milk composition and yield during different seasons, breeds, environmental conditions, feedings, and stages of lactation within a milking goat. Nutrition (forage-toconcentrate ratio, type of forages, etc.) is the main environmental factor regulating milk fat synthesis and fatty acid composition in ruminants (Bernard et al., 2009). Abkhazian and Kackar goat are local breeds, and their milk nutrient contents/profiles have not been studied.

Milk lipids commonly consist of $98 \%-99 \%$ TAG, which are located in the fat globule. The remaining $1 \%$ $2 \%$ are minor lipid components, including DAG (0.3\%- 
$1.6 \%)$, monoacylglycerols $(0.002 \%-0.1 \%)$, PL ( $0.2 \%-1.0 \%)$, cerebrosides $(0.01 \%-0.07 \%)$, sterols $(0.2 \%-0.4 \%)$, and FFA $(0.1 \%-0.4 \%)$ (Renner et al., 1989). In this study, Abkhazian and Kackar goat milk fats had lower TAG, while higher DAG, FFA, CHOL, and PL percentages in total lipid (Table 1) than those reported in the literature.

Breed appears to be a major factor regulating protein synthesis in mammary gland. Costa et al. (2014) reported that the total amount of protein was $3.15 \mathrm{~g} / \mathrm{dl}$ and $3.60 \mathrm{~g} / \mathrm{dl}$, respectively, in Saanen and Alpine goat milk in the north-east of Brazil. The total amount of protein in human, cow, and goat milks were reported to be 10 $\mathrm{g} / \mathrm{L}, 34 \mathrm{~g} / \mathrm{L}$, and $33 \mathrm{~g} / \mathrm{L}$, respectively (Greppi et al., 2008). The protein concentration in these local goat species (Table 2) was greater than dairy goat species previously reported (Silanikove et al., 2010).

Milk proteins can be classified in 3 major classes: milk fat globule proteins (MFGM), caseins, and whey proteins. Casein is insoluble, while whey proteins are soluble proteins. Milk fat globules are surrounded by a membrane that mainly consists of proteins, phospholipids, glycoprotein, triglycerides, cholesterol, and enzymes. This membrane is known as milk fat globule membrane (MFGM) and consists of a few layers of different origins (Zamora et al., 2009). Milk fat globules are produced in mammary glands during breast feeding and their structures consists of double phospholipid membrane. $25 \%-70 \%$ of MFGM consists of proteins depending on the milk source and process. As the globule typology and protein content of milk fat vary among farm animal species, the structure and function of MFGM proteins attract great attention (Roncada et al., 2012).

The MGFM proteins have certain physiological benefits, which include to act as natural emulsifying agents, prevent flocculation and the unification of fat globules and protect fat against enzyme activity. The biggest MFGM protein is MUC1 (Zamora et al., 2009). The molecular weight was approximately $162 \mathrm{kDa}$ and made up $0.78 \%$ of the total protein. Mather (2000) found the molecule weight of CD36 in cow milk was in the range of 75 and $88 \mathrm{kDa}$, while Zamora et al. (2009) found that the molecule weight of CD36 in goats was about $83 \mathrm{kDa}$. The percentage of BTN protein in cows depending on delivery varies within MFGM proteins. In many studies, the BTN proteins gave 2 bands at 67 and $64 \mathrm{kDa}$ when they were fragmented as a result of proteolysis from SDS-PAGE (Heid et al., 1983). Zamora et al. (2009) indicated that the molecular weight of BTN protein was $68 \mathrm{kDa}$ in goat milk, being the second biggest MFGM protein. The PAS 6/7, another MFGM protein, is the most abundant MFGM glycoprotein after BTN protein, and it was reported that range of their molecular weights was from $43 \mathrm{kDa}$ to $59 \mathrm{kDa}$ (Mather, 2000). Hvarregaard et al. (1996) determined that the PAS 6/7 presented two bands in 50 and $47 \mathrm{kDa}$, respectively. Atmani et al. (2004) found that the molecular weight of goat $\mathrm{XO}$ as a single band was $150 \mathrm{kDa}$ and it constituted $0.69 \%-1.81 \%$ of total protein. The molecular weights and fractional percentages of MFGM proteins in local goat milk (Figure 1; Table 2) were in agreement with those reported in literature.
Caseins consist of micelles in suspension, which are approximately $190 \mathrm{~nm}$ in diameter. Caseins are connected with calcium phosphate, small amount of magnesium, sodium, and citrate. These disperse the light and give a white opaque look to milk (Park et al., 2007). The main caseins in goat milk are the same as those in sheep and cow, and named as $\alpha_{\mathrm{S} 1}$-casein $\left(\alpha_{\mathrm{S}_{1}}-\mathrm{CN}\right), \alpha_{\mathrm{S} 2}-$ casein $\left(\alpha_{\mathrm{S}_{2}}-\mathrm{CN}\right), \beta$-casein $(\beta-\mathrm{CN})$, and $\kappa$-casein $(\kappa-\mathrm{CN})$ (Park et al., 2007; Hama et al., 2010). Furthermore, the genetic polymorphism and fractions of casein content in goat breeds are different (Raynal-Ljutovaca et al., 2008). Potocnik et al. (2011) reported that the percentages of $\alpha$-casein were $40.2 \%-59.0 \%$ in mares, $48.3 \%-48.5 \%$ in cows, $21.2 \%-32 \%$ in goats, and $11.1 \%-12.5 \%$ in humans; the percentage of $\beta$-casein as $40.1 \%-51.4 \%$ in mares, $35.8 \%-37.9 \%$ in cows, $39.95 \%$ in sheep, $48 \%-60 \%$ in goats, and $62.5 \%-66.7 \%$ in humans; the percentages of $\kappa$-casein were $7.71 \%$ in mares, $9.32 \%$ in sheep, between $12.7 \%-13.8 \%$ in cows, $12 \%-20 \%$ in goats, and $22.2 \%-$ $25.0 \%$ in humans. The amount of casein is low in goat breeds and the amount of $\alpha$-casein among casein fractions is lower than that of $\beta$-casein. Salem et al. (2009) reported that the proportion of $\beta$-casein $(70.2 \%)$ was predominant fraction and the proportion of $\alpha$-casein $(29.85 \%)$ was minimal fraction. All casein fractions in Abkhazian and Kackar goat milk were lower than those reported in dairy goats (Table 2), but their fractional rank orders were similar.

Whey proteins (more than $80 \%$ ) are immunoglobines, $\alpha$-lactalbumin, lactoferrin, $\beta$-lactoglobin, serum albumin, and lactoperoxidase (Gupta et al., 2012; Casado et al., 2009). Certain whey proteins support health and reduce disease risks. When whey proteins are used as dietary substances or supplements, they ensure the increase of antimicrobial activity, immune modulator, and muscle power. They can also delay the onset and/or help the heal of diseases such as osteoporosis, cardiovascular diseases, obesity, and cancer (Casado et al., 2009). The proportion of $\alpha$-lactalbumin is high in cows milk, which leads to allergic reactions in many individuals. $\beta$-lactoglobin is the main whey protein in sheep, mares, and goats although it is not present in human milk (Potocnik et al., 2011). This protein type is allergic form in milk proteins and responsible for the onset of the allergy that affect numerous babies that are fed on other milk than breast milk (Hochwallner et al., 2014). Potocnik et al. (2011) reported that the percentage of $\beta$-lactoglobin was $25.3 \%-36.3 \%$ in mares, $18.4 \%-20.1 \%$ in cows, $59.24 \%-77.70 \%$ in sheep, and $43.54 \%-63.80 \%$ in goats. The percentage of $\alpha$-lactalbumin was $27.5 \%-29.7 \%$ in mares, $52.9 \%-53.6 \%$ in cows, $8.97 \%-17.00 \%$ in sheep, $13.31 \%-34.70 \%$ in goats, and $30.3 \%-45.4 \%$ in humans. Both local goat species had much lower $\beta$-lactoglobin and $\alpha$-lactalbumin percetages than dairy goat species (Table 2), which could replace milk causing allergy in infant nutrition.

\section{CONCLUSION}

Despite reared under the same ecosystem and subjected to the same management protocols, Abkhazian and Kackar goat milk differed in total fat concentration 
and percentages of TAG, FFA, and DAG. The concentration of total protein and the fractions of whey proteins, MFGM proteins, and caseins were also different between Kackar and Abkhazian goats. The differences in the fat and protein profiles in milk between goat breeds may depend on genetic factors. Milk from both local goats can be an option to eliminate problems arising due to allergic reactions in infant nutrition.

\section{ACKNOWLEDGEMENT}

This work was supported by the Department of Science Research Project at Artvin Coruh University.

\section{REFERENCES}

Atmani, D., M. Benboubetra, \& R. Harrison. 2004. Goat's milk xanthine oxidoreductase is grossly deficient in molybdenum. J. Dairy. Res. 71: 7-13. https://doi.org/10.1017/ S0022029903006514

Bernard, L., K. J. Shingfield, J. Rouel, A. Ferlay, \& Y. Chilliard. 2009. Effect of plant oils in the diet on performance and milk fatty acid composition in goats fed diets based on grass hay or maize silage. Br. J. Nutr. 101: 213-224. https://doi.org/10.1017/S0007114508006533

Casado, B., M. Affolter, \& M. Kussmann. 2009. OMICS rooted studies of milk proteins, oligosaccharides and lipids. J. Proteomics. 73: 196-208. https://doi.org/10.1016/j. jprot.2009.09.018

Ceballos, L. S., E. R. Morales, G. T. Adarve, J. D. Castro, L. P. Martinez, \& M. R. Sanz-Sampelayo. 2009. Composition of goat and cow milk produced under similar conditions and analyzed by identical methodology. J. Food. Comp. Anal. 22: 322-329. https://doi.org/10.1016/j.jfca.2008.10.020

Costa, W. K., E. L. Souza, E. M. Beltrão Filho, G. K. Vasconcelos, T. Santi Gadelha, C. A. de Almeida Gadelha, O. L. Franco, Rita de Cássia Ramos do Egypto Queiroga, \& M. Magnani. 2014. Comparative protein composition analysis of goat milk produced by the Alpine and Saanen breeds in northeastern Brazil and related antibacterial activities. Plos. One. 9: 1-8. https://doi.org/10.1371/journal. pone. 0093361

Domagala, J. 2009. Instrumental texture, syneresis and microstructure of yoghurts prepared from goat, cow and sheep milk. Int. J. Food. Prod. 12: 605-615. https://doi. org/10.1080/10942910801992934

Drewnowski, A. \& V. Fulgoni III. 2008. Nutrient profiling of foods:creating anutrientrichfood index.Nutr.Rev.66:23-39. https://doi.org/10.1111/j.1753-4887.2007.00003.x

Fossati, P. \& L. Prencipe. 1982. Serum triglycerides determined colorimetrically with an enzyme that produces hydrogen peroxide. Clin. Chem. 28: 2077-2080.

Greppi, G. F., P. Roncada, \& R. Fortin. 2008. Protein Components of Goat's Milk. In: G Pulina, \& A. Cannas (Eds.) Dairy Goats Feeding And Nutrition, 2 ed. Bologna, CAB International p. 71-94. https://doi.org/10.1079/9781845933487.0071

Gupta, C., D. Prakash, A. P. Garg, \& S. Gupta. 2012. Whey Proteins: A novel source of Bioceuticals. Mid. East J. Sci. Res. 12: 365-375.

Hama, J. S., S. G. Leea, S. G. Jeonga, M. H. Oha, D. H. Kima, \& Y. W. Park. 2010. Characteristics of Korean-Saanen goat milk caseins and somatic cell counts in comparison with Holstein cow milk counterparts, Small Rumin. Res. 93: 202-205 https://doi.org/10.1016/j.smallrumres.2010.05.006

Hara, A. \& N. S. Radin. 1978. Lipid extraction of tissues with a low-toxicity solvent. Anal. Biochem. 90: 420-426. https://doi.org/10.1016/0003-2697(78)90046-5

Heid, H. W., S. Winter, G. Bruder, T. W. Keenan, \& E. D. Jarasch.
1983. Butyrophilin, an apical plasma membrane-associated glycoprotein characteristic of lactating mammary glands of diverse species. BBB. Biomembranes. 728: 228-238. https://doi.org/10.1016/0005-2736(83)90476-5

Hochwallner, H., U. Schulmeister, I. Swoboda, S. Spitzauer, \& R. Valenta. 2014. Cow's milk allergy: From allergens to new forms of diagnosis, therapy and prevention. Methods. 66: 22-33. https://doi.org/10.1016/j.ymeth.2013.08.005

Hvarregaard, J., M. H. Andersen., L. Berglund, J. T. Rasmussen, \& T. E. Petersen. 1996. Characterization of glycoprotein PAS-6/7 from membranes of bovine milk fat globules. Eur. J. Biochem. 240: 628-636. https://doi. org/10.1111/j.1432-1033.1996.0628h.x

Kaynar, O., M. Ileriturk, \& A. Hayirli. 2013. Evaluation of Computational modifications in HTLC with gel analysis software and flatbed scanner for lipid separation. Journal of Planar Chromatography Modern TLC. 26: 202-208. https://doi.org/10.1556/JPC.26.2013.3.1

Kücükcetin, A., M. Demir, A. Asc1, \& E. M. Comak. 2011. Graininess and roughness of stirred yoghurt made with goat's, cow's or a mixture of goat's and cow's milk. Small Rumin. Res. 96: 173-177. https://doi.org/10.1016/j. smallrumres.2010.12.003

Laemmli,U.K.1970. Cleavage of structural proteins during theassembly of the head of bacteriophage T4. Nature. 227:680-885. https://doi.org/10.1038/227680a0

Lowry, O. H., N. J. Rosebrough, A. L. Farr, \& R. J. Randall. 1951. Protein measurement with the Folin phenol reagent. J. Biol. Chem.193: 265-275.

Markiewicz-Kęszycka, M., G. Czyżak-Runowska, P. Lipińska, \& J. Wójtowski. 2013. Fatty acid profile of milk - A review. Bull. Vet. Inst. Pulawy 57: 135-139.

Mather, I. H. 2000. A review and proposed nomenclature for major proteins of the milk-fat globule membrane. J. Dairy. Sci. 83: 203-247. https://doi.org/10.3168/jds. S0022-0302(00)74870-3

Park, Y. W., M. Juarez, M. Ramos, \& G. F. W. Haenlein. 2007. Physico-chemical characteristics of goat and sheep milk. Small Rumin. Res. 68: 88-113. https://doi.org/10.1016/j. smallrumres.2006.09.013

Potocnik, K., V. Gantner, K. Kuterovac, \& A. Cividini. 2011. Mare's milk composition and protein fraction in comparison with different milk species. Mljekarstvo. 61: 107-113.

Raynal-Ljutovac, K., G. Lagriffoul, P. Paccard, I. Guillet, \& Y. Chilliard. 2008. Composition of goat and sheep milk products: An update. Small Rumin. Res. 79: 57-72. https://doi.org/10.1016/j.smallrumres.2008.07.009

Renner, E., G. Schaafsma, \& K. J. Scott. 1989. Micronutrients in milk. In: E Renner E. (Ed.): Micronutrients in Milk and Milk Based Products, Elsevier Applied Science, New York: p. 1-70

Roncada, P., C. Piras, A. Soggiu, R. Turk, A. Urbani, \& L. Bonizzi. 2012. Farm animal milk proteomics. J. Proteomics. 75: 4259-4274 https://doi.org/10.1016/j.jprot.2012.05.028

Salem, S. A., E. I. El Agamy, F. A. Salama, \& N. H. Abo Soliman. 2009. Isolation, Molecular and Biochemical Characterization of Goat Milk Casein and Its Fractions. Trop. Subtrop. Agroecosyst. 11: 29-35.

SAS. 2002. User's Guide. Statistics, Version 9th. Statistical Analysis System. SAS Inst., Inc., Cary, NC, USA.

Silanikove, N., G. Leitner, U. Merin, \& C. G. Prosser. 2010. Recent advances in exploiting goat's milk: quality, safety and production aspects. Small Rumin. Res. 89: 110-124. https://doi.org/10.1016/j.smallrumres.2009.12.033

Yangilar, F. 2013. As a potentially functional food: Goats' milk and products. J. Food. Nutr. Res. 4: 68-81.

Zamora, A., B. Guamis, \& A. J. Trujillo. 2009. Protein composition of caprine milk fat globule membrane. Small Rumin. Res. 82: 122-129. https://doi.org/10.1016/j. smallrumres.2009.02.010 